удк 621.039.512

Yu. N. Ovdiienko' ${ }^{1}$ M. L. Yeremenko ${ }^{1}$, V. A. Khalimonchuk ${ }^{1}$, A. V. Kuchin ${ }^{1}$, Yu. M. Bilodid ${ }^{2}$

${ }^{1}$ State Scientific and Technical Center for Nuclear and Radiation Safety, Kyiv, Ukraine

2 HZDR, Dresden, Germany

\section{Effect of Fuel Burnup History on Neutronic Characteristics of WWER-1000 Core}

In preparation of few-group cross-section libraries to be used in WWER macro-calculations, change in the nuclide composition during fuel burnup is commonly defined under invariable characteristics, averaged over the entire core (power, fuel and moderator temperature, moderator density etc.). In reality, conditions of fuel burnup are changing and this factor affects the fuel nuclide composition (the so-called spectral history effect). To account for real burnup history, it is necessary to take into consideration the dependence of cross-sections not only on burnup but also on history of neutron spectrum in the fuel burnup process.

This paper analyzes fuel burnup history effect on neutronic characteristics of WWER-1000 core with use of the DYN3D code. The DYN3D code employs the local Pu-239 concentration as an indicator of burnup spectral history. The calculations have been performed for the first four fuel loadings of Khmelnitsky NPP unit 2 and stationary fuel loading with TVSA. The effect of fuel burnup history is shown both on macro-characteristics of the reactor core (boric acid concentration, fuel cycle duration, reactivity coefficients) and on local values of burnup and power.

Ke y word s: WWER, spectral effect, fuel burnup, cross-section library.

Ю. М. Овдієнко, М. Л. Єременко, В. А. Халімончук, О. В. Кучин, ю. М. Білодід

\section{Вплив урахування історії вигоряння палива на розрахункові НФХ ВВЕР-1000}

Зазвичай у процесі підготовки малогрупової бібліотеки констант для використання в великосіткових програмах розрахунку реакторів ВВEP змінення ізотопного складу палива в ході вигоряння визначається за незмінних, усереднених по всій активній зоні, характеристик (потужність, температура палива і сповільнювача, щільність сповільнювача тощо). У реальності умови вигоряння палива змінюються і це, в свою чергу, впливає на ізотопний склад (так званий історичний або спектральний ефект). Щоб урахувати реальну історію вигоряння (спектральний ефект), треба врахувати залежність перерізів взаємодії не тільки від вигоряння, а й самої історії змінення спектра нейтронів протягом вигоряння палива.

У статті наведено результати оцінки впливу спектрального ефекту на розрахункові нейтронно-фізичні характеристики активної зони BBEP-1000, виконані з використанням розрахункового коду DYN3D. У коді реалізовано метод урахування спектрального ефекту, заснований на використанні концентрації ${ }^{39} \mathrm{P}$ як індикатора історії вигоряння. Розрахункові дослідження виконано для чотирьох паливних завантажень 2-го блока Хмельницької АЕС. Показано вплив урахування історичного ефекту як на макрохарактеристики активної зони (концентрація борної кислоти, тривалість кампанії, коефіцієнти реактивності), так іна розподіл локальних значень вигоряння та енерговиділення.

Ключов і слов а: ВВЕР, спектральний ефект, вигоряння палива, нейтронно-фізичні константи.

(C) Yu. N. Ovdiienko, M. L. Yeremenko, V. A. Khalimonchuk, A. V. Kuchin, Yu. M. Bilodid, 2014 he procedure for preparing few-group cross-section libraries to be used for WWER macro-calculations commonly involves calculation of the change in nuclide composition during fuel burnup under invariable characteristics, averaged over the entire core (power, fuel and moderator temperature, moderator density etc.). In reality, conditions of fuel burnup are changing and this factor influences the fuel nuclide composition (the so-called spectral history effect).

For example, considering change of coolant density in axial direction typical of WWER-1000 $\left(0.68 \div 0.76 \mathrm{~g} / \mathrm{cm}^{3}\right.$ from core bottom to upper part), the difference of ${ }^{239} \mathrm{Pu}$ concentration due to spectral change can reach $10 \%$ (Fig. 1) under fuel burnup $50 \div 60 \mathrm{MW}^{*}$ days $/ \mathrm{kgU}$ and for eigenvalue up to $\Delta \mathrm{K}_{\mathrm{inf}}=0.026$ (Fig. 2).

Besides coolant density, the fuel temperature, boron acid concentration and presence of absorber rods have valuable impact on change in nuclide composition during fuel burnup. Neglect of spectral effect during few-group cross-section library preparation may lead to an additional error in neutronic characteristics of the reactor core. Therefore, to account for actual burnup history, it is necessary to take into consideration the dependence of cross-sections not only on burnup, but also on history of neutron spectrum during fuel burnup.

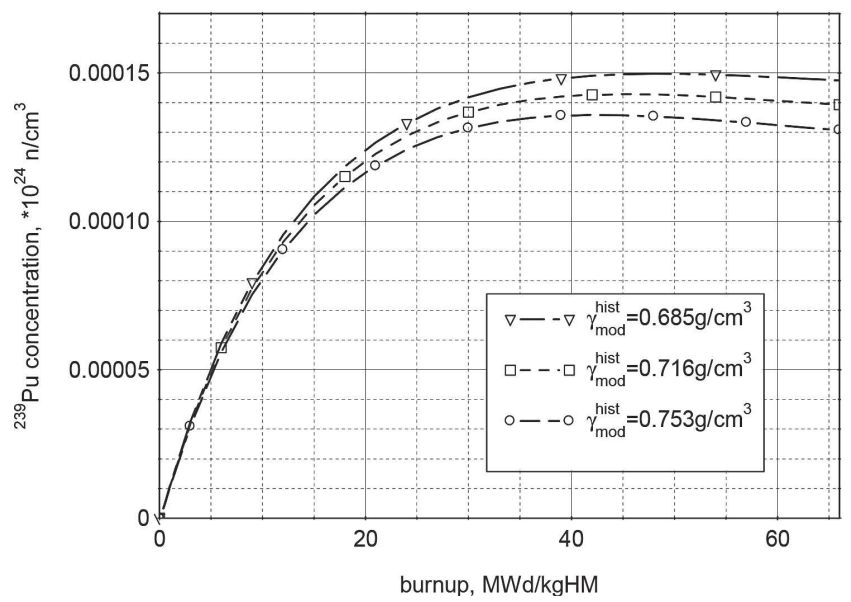

Fig. 1. ${ }^{239} \mathrm{Pu}$ concentration under different moderator density burnup histories for FA 398GO

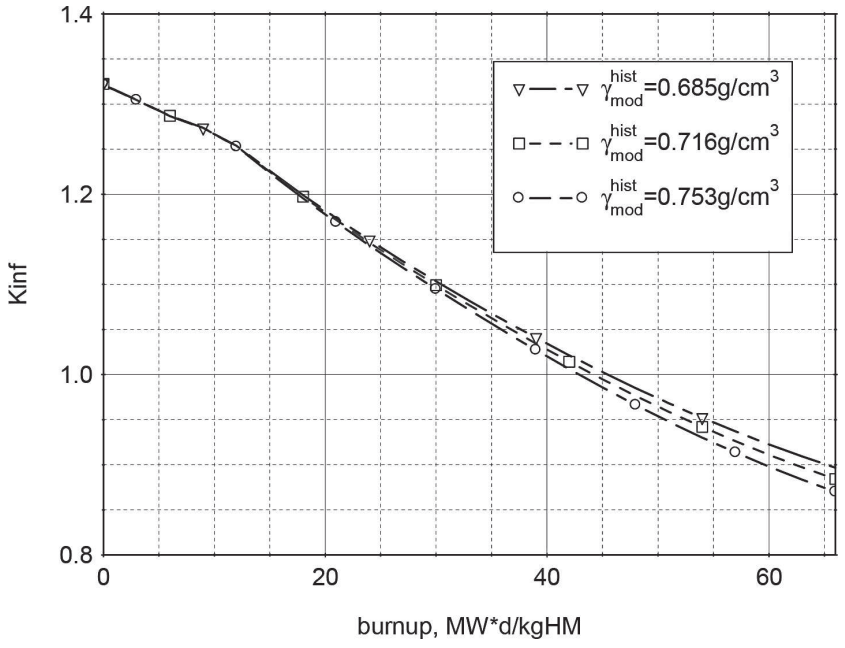

Fig. 2. Multiplication factor for FA $398 \mathrm{GO}$ under different moderator density burnup histories 
The objective of this paper is to assess the fuel burnup history effect during few-group cross-section library preparation on neutronic characteristics of WWER-1000 core. The studies are performed with use of the DYN3D code [1].

\section{Account of Burnup History Effect}

The studies of the burnup history effect on few-group crosssections for PWR reactors are presented in [2, 3]. The studies were conducted with the HELIOS spectral code and involved assessment of change in cross-sections under variation of one or several parameters characterizing fuel burnup conditions (coolant and fuel temperature, coolant density, boric acid concentration). Based on the studies, the method to account for burnup history effect with use of ${ }^{239} \mathrm{Pu}$ concentration as a burnup history indicator was proposed by Helmholtz-Centre DresdenRossendorf [2]. The proposed method of accounting for burnup history effect suggests the following correction of cross-section dependence on burnup history:

$$
\Sigma^{\text {actual }}=\Sigma^{\text {base }} \cdot\left(1+k_{h} \sqrt{\frac{N_{P u}-N_{P u}^{\text {nominal }}}{N_{P u}^{\text {nominal }}}}\right),
$$

where $\Sigma^{\text {base }}$ is the nodal macroscopic cross-section calculated in the standard way; $N_{P u}$ nominal is concentration of ${ }^{9} \mathrm{Pu}$ in the standard depletion; $N_{P u}$ is actual local ${ }^{9} \mathrm{Pu}$ concentration; $k_{h}$ is history coefficient, proportionality factor between difference in ${ }^{9} \mathrm{Pu}$ concentration and difference in macroscopic cross-section.

History coefficients are relation between relative change of the cross-section and relative change of the history indicator:

$$
k_{h}=\Delta \Sigma / \Delta P u=\frac{\Sigma_{1}-\Sigma_{0}}{\Sigma_{0}} \cdot \frac{\sqrt{N_{P u 0}}}{\sqrt{N_{P u 1}}-\sqrt{N_{P u 0}}} .
$$

The proposed method was introduced in the DYN3D code. Assessment of accounting for burnup history effect on neutronic characteristics of WWER-1000 core is performed with use of this code.

To analyze the steady value of accounting for burnup history effect, it is necessary to model more than four fuel cycles for obtaining both steady burnup and plutonium distributions. In transitional fuel loadings (the term "transitional fuel loadings" is used in terms of transition to account of burnup history effect but not fuel pattern), the effect of compensation of multiplication capacity increases by higher burnup rate and contrariwise.

In this work, the fuel burnup history effect for the first four fuel loadings of Khmelnitsky NPP unit 2 and for eight sequential fuel loadings of stationary fuel cycle with TVSA fuel assemblies of Russian design is assessed.

\section{Results of Calculations for Stationary Fuel Loading}

Eight fuel loadings were simulated for assessment of the fuel burnup history effect in stationary fuel cycle with TVSA fuel assemblies of Russian design: the first four are transitional fuel loadings and loadings 5 to 8 are stationary in terms of fuel loading pattern. Modeling of eight fuel loadings is stipulated by necessity of obtaining of steady value of accounting of burnup historical effect.

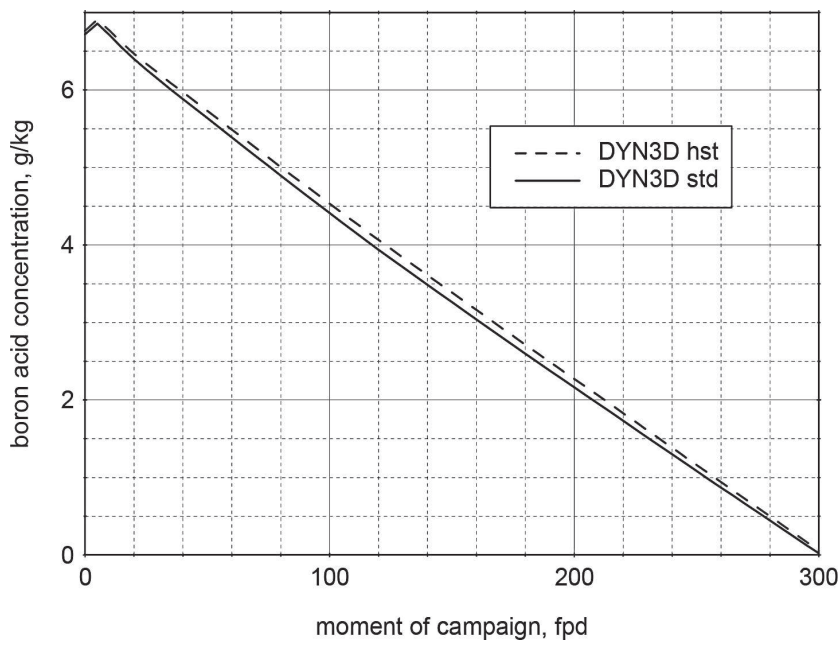

Fig. 3. Boric acid concentration during stationary fuel cycle

The analysis has shown that the account of historical effect does not make an essential impact on integral core characteristics. So fuel cycle durations that account for the historical effect (signed hst in the presented figures) and do not account for the historical effect $(s t d)$ differ by less than $1.5 \mathrm{fpd}$. However, in the middle of fuel cycle, the difference in boric acid concentration can reach $\approx 0.15 \mathrm{~g} / \mathrm{kg}$ (Fig. 3); but up to the end of the fuel cycle the difference decreases up to the hundredth part $(\approx 0.02 \div 0.03 \mathrm{~g} / \mathrm{kg})$. It is caused by the effect of compensation of multiplication capacity increase: the reactor core parts with greater plutonium concentration due to account of historical effect (boric acid concentration is greater) are burning more intensively (the difference in boron acid concentration for cases with and without account of the historical effect decreases after the middle of fuel cycle).

Another factor that leads to the minimal influence of the account for historical effect on integral core characteristics is definition of isotope composition for the fuel and moderator temperature averaged over the core, moderator density corresponding to rated level of power. Therefore, under rated level of power, the influence of the historic effect will more likely concern local characteristics: for example, axial power distribution owing to a steady gradient of moderator density in the axial direction.

The analysis of the historical effect account has revealed insignificant impact on relative fuel assembly (FA) power distribution as well (Fig. 4). It is caused, first, by insignificant difference of real integral concentration of plutonium in FA, second, by small difference between the real plutonium concentration in FAs and plutonium concentration introduced in the standard cross-section library and prepared with use of rated power FA parameters, third, by sufficiently smooth radial power distribution and, fourth, the aforementioned effect of self-compensation of multiplication capacity by burnup.

As it is supposed above, the historical effect account makes the most essential impact on the axial power profile. Owing to decrease of moderator density in the axial direction (on the average from 0.76 to $0.68 \mathrm{~g} / \mathrm{cm}^{3}$ ), the neutron spectrum in the top core part leads to greater accumulation of plutonium and, accordingly, to increase of multiplication capacity. Thus, there is displacement of the axial power profile in the top core part: the maximum value of displacement for stationary fuel 


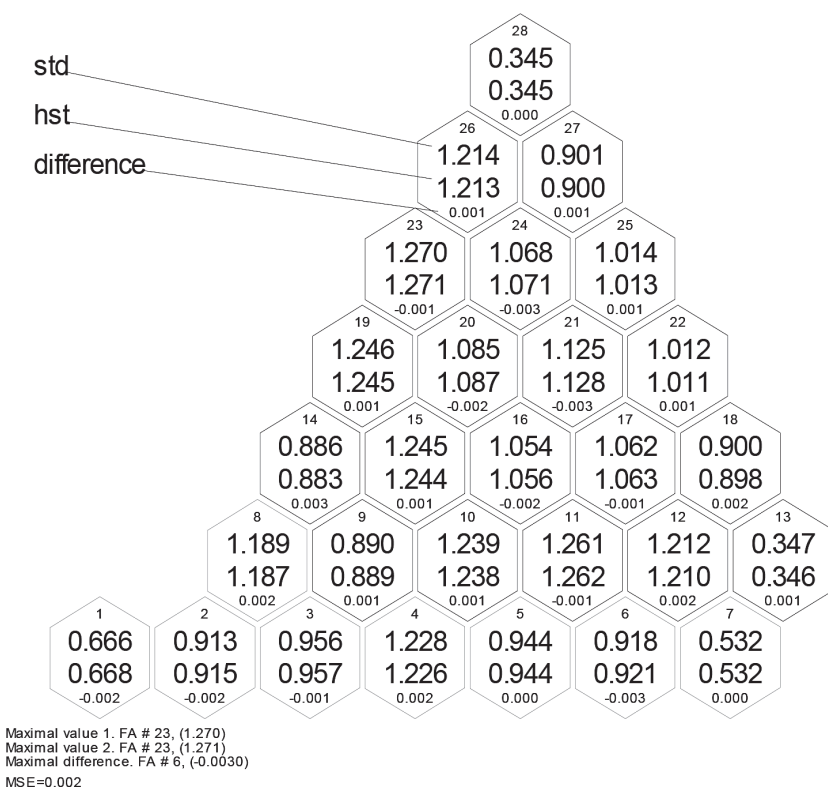

Fig. 4. Relative FA power at the beginning of stationary fuel cycle

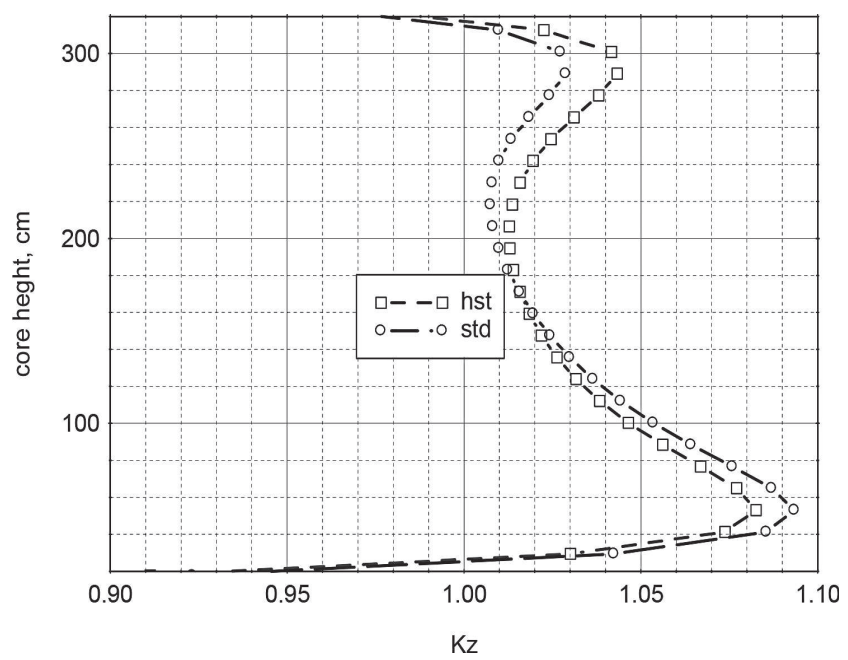

Fig. 6. Axial power profile in the core at the end of fuel cycle

loading amounts to $\Delta \mathrm{Kz} \approx 0.02$ at height $\approx 90 \%$ from the core bottom (Fig. 5, 6).

Concerning the axial power profile in individual Fas, the following can be noted. The greatest difference in FA axial profiles under account of the historical effect are is observed in the bottom layers (up to $5 \%$ ) and in the top layers at the level of $90 \%$ from the core bottom (up to $3 \%$, Fig. 7).

\section{Results of Calculations for Khmelnitsky NPP Unit 2}

Calculations for Khmelnitsky NPP unit 2 have been performed beginning from the first fuel loading fully composed by fresh fuel. Under these calculations, there is possibility to compare the received results with experimental values of axial power distribution in FAs, boric acid concentration and efficiency of control rods (CR) [4].

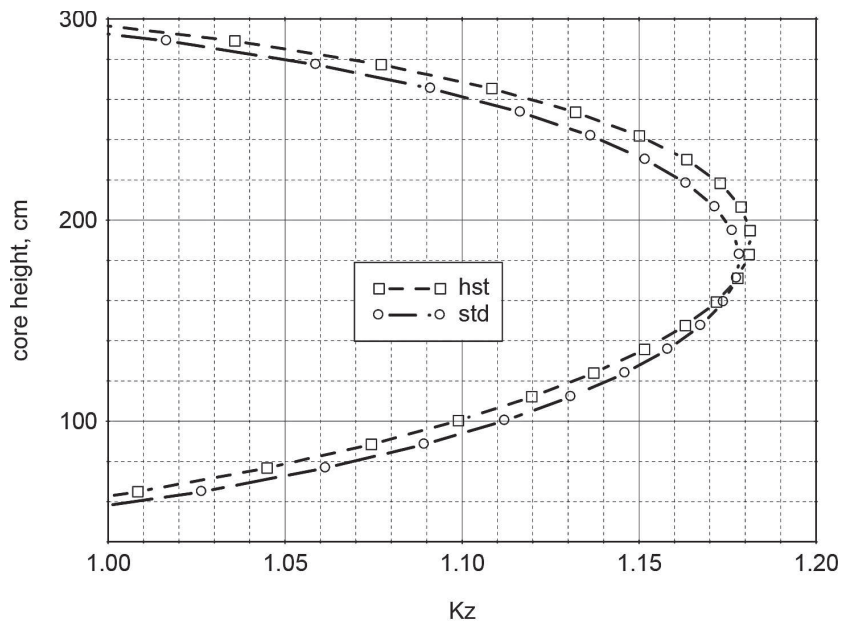

Fig. 5. Axial power profile in the core at the beginning of fuel cycle

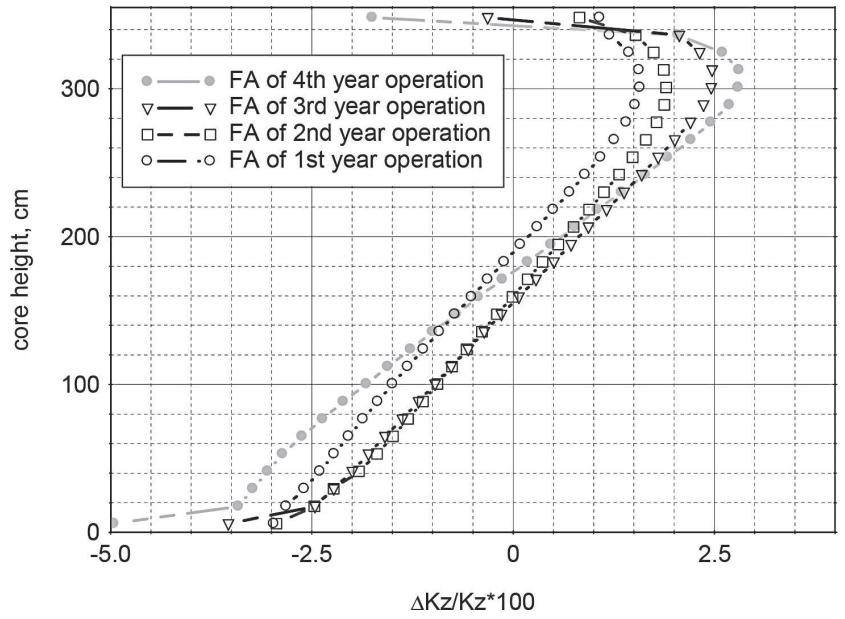

Fig. 7. Impact of historical effect for FAs of different operation durations

Results of the analysis show that influence of the historical effect on concentration of boric acid during the first fuel cycle is similar to the results presented in the previous section for stationary fuel cycle. However, in this given case the effect on boric acid concentration is greater and amounts to $\Delta C_{b} \approx 0.12 \mathrm{~g} / \mathrm{kg}$. It is caused by the essential difference of the reactor power diagram for the first fuel cycle from rated power, which is $\approx 100 \mathrm{fpd}$. Considering that further ( $2 \div 4$ fuel cycles) power diagrams were close to the rated value, the effect of account decreased for $C_{b}$ to $\approx 0.05 \div 0.07 \mathrm{~g} / \mathrm{kg}$.

Results of computer modeling have revealed the essential influence of historical effect on axial power distribution already at the end of the first cycle (264 fpd). So, the burnup historical effect on axial power distribution reaches $2.5 \div 3 \%$ (for FAs with average initial enrichment of $1.3 \%$ and $\approx 10 \mathrm{MW} \cdot$ days $/ \mathrm{kgU}$, Fig. 8). In the fourth fuel cycle, the effect of burnup history account for FAs of the first year of operation decreases to $1 \%$, 
Effect of Fuel Burnup History on Neutronic Characteristics of WWER-1000 Core

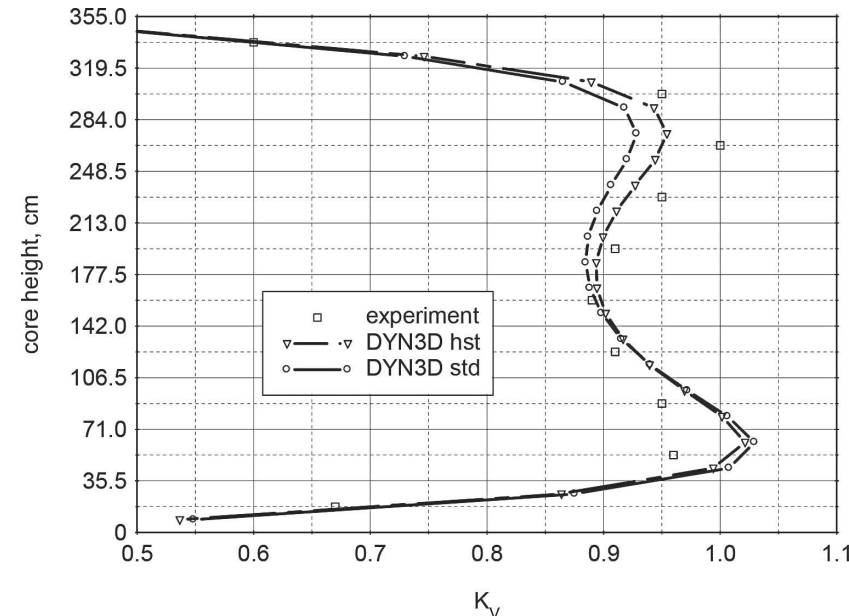

Fig. 8. Axial power profile in FA with $1.3 \%$ average initial enrichment (end of the first fuel cycle)

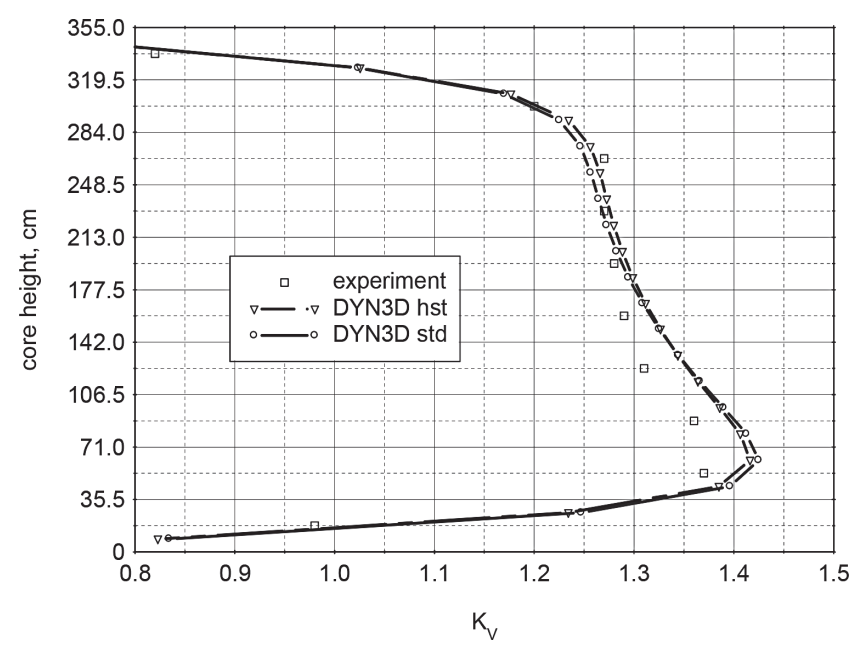

Fig. 9. Axial power profile in FA of the first year of operation (end of the fourth fuel cycle)

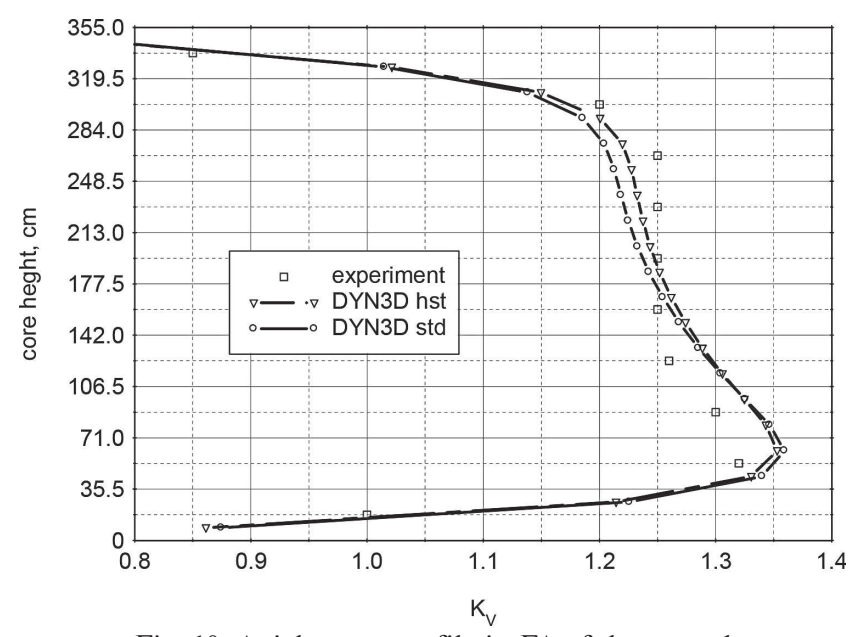

Fig. 10. Axial power profile in FA of the second year of operation (end of the fourth fuel cycle)

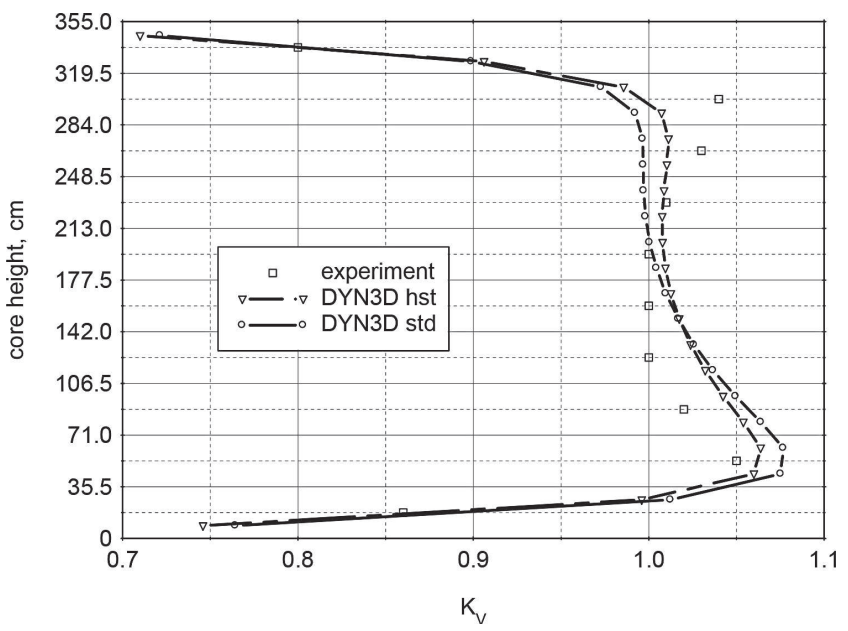

Fig. 11. Axial power profile in FA of the third year of operation (end of the fourth fuel cycle)

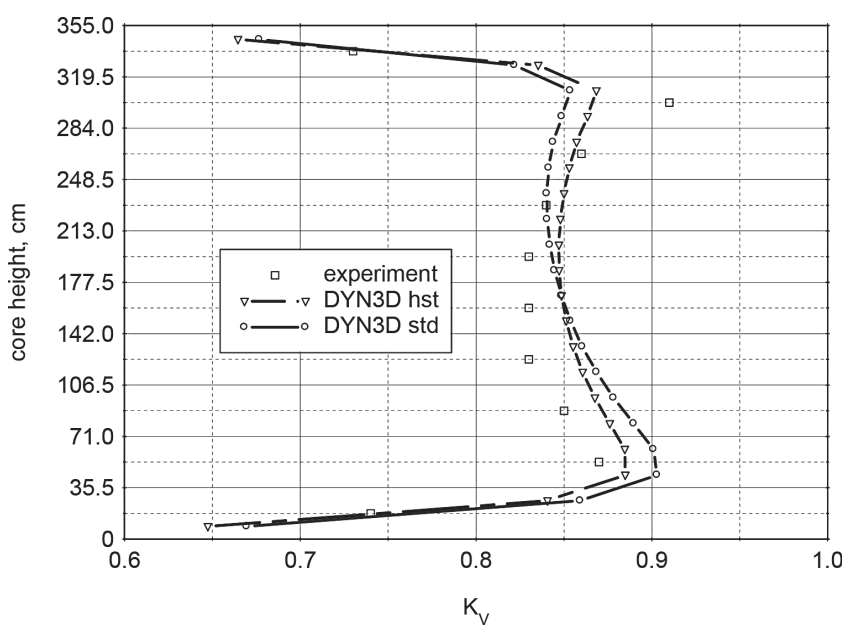

Fig. 12. Axial power profile in FA of the fourth year of operation (end of the fourth fuel cycle)

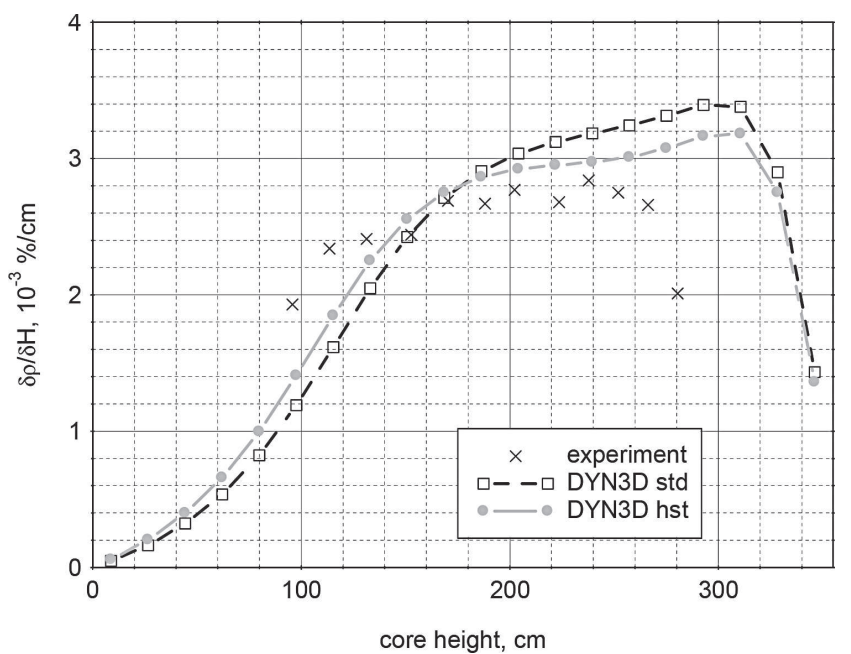

Fig. 13. Differential efficiency in control rods of the working group (beginning of the fourth fuel cycle) 
and for FAs of the third and fourth year of operation amounts to approximately $1.5 \div 2 \%$ (Fig. 9-12). It is necessary to note that influence of the historical effect account on axial power distribution of individual FA depends not only on the year of operation (fuel burnup), but also on its location in the reactor core because of the impact of surrounding FAs. Because of the influence of historical effect on the axial power profile, it is necessary to assume its influence on the differential efficiency of control rods as well (Fig. 13).

\section{Conclusions}

1. The neglect of the burnup history leads to an additional error component in the calculation of ${ }^{239} \mathrm{Pu}$ concentration up to $\pm 6 \%$ for burned WWER-1000 FAs.

2. The account of the historical has no essential influence on integral core characteristics under reactor operation at power close to the rated value in comparison with the results of calculations with use of the standard cross-section library, in which isotope composition was defined under parameters averaged over the core (fuel and moderator temperature, moderator density etc.) corresponding to the rated level of power.

3. The account of the historical effect increases the accuracy of calculations of FA axial power profile by $2.5 \div 3 \%$. Comparison of the calculated and experimental data shows that the account of historical effect leads to similar calculated axial power distribution and differential efficiency of control rods in the working group and experimental data in all considered cases.

\section{References}

1. Grundmann U., Rohde U., Mittag S., Kliem S. DYN3D, Version 3.2, Code for calculation of transient in Light Water Reactors (LWR) with Hexagonal or Quadratic Fuel Elements. Description of Models and Methods // Report FZR-434, Rossendorf (2005)

2. Bilodid I., Mittag S: Use of the local Pu-239 concentration as an indicator of burnup spectral history in DYN3D // Annals of Nuclear Energy. - 2010. - No. 37. - P. 1208-1213.

3. Bilodid Y., Ovdiienko I., Mittag S., Kuchin A., Khalimonchuk V., Ieremenko M. Assessment of spectral history influence on PWR and WWER core // Kerntechnik. -2007. - No. 77(2012)4, KT11025. P. $278-285$.

4. Lutsch T., Khalimonchuk V., Kuchin A. Proposal of a Benchmark for Core Burnup Calculations for a VVER-1000 Reactor Core // Proceeding of the 19th Symposium of AER on VVER Reactor Physics and Reactor Safety. -2009 . 